\title{
26. LIPID GEOCHEMISTRY OF CRETACEOUS SEDIMENTS FROM VIGO SEAMOUNT, DSDP/IPOD LEG 47B ${ }^{1}$
}

\author{
Bernd R. T. Simoneit and Monica A. Mazurek, Institute of Geophysics and Planetary Physics, \\ University of California, Los Angeles, California
}

\begin{abstract}
Lower Paleocene and Cretaceous sediments taken from Hole 398D, south of Vigo Seamount, were inspected for lipid content. Evidence of bacterial origin was indicated by the lipid distribution of the lower Paleocene sample. The lipid residues of the two Cretaceous samples gave significantly different patterns with respect to the degree of autochthonous and allochthonous input and to the level of petrogenic maturity.
\end{abstract}

\section{INTRODUCTION}

Cretaceous black shales and mudstones have been analyzed from many DSDP sites in the Atlantic Ocean, and some of these areas were anoxic basins with high sedimentation rates and a large influx of terrigenous detritus (Simoneit, 1978a). Therefore, it is of interest to determine if, in the case of the sediments from the northeastern Atlantic Ocean, the analyses of the lipids would allow a distinction to be made between the autochthonous marine and allochthonous terrigenous sources, and if some inferences about the paleoenvironmental conditions of sedimentation could be proposed.

The samples were derived on DSDP/IPOD Leg 47B from Hole 398D, located immediately south of Vigo Seamount $\left(40^{\circ} 57.6^{\prime} \mathrm{N}, 10^{\circ} 43.1^{\prime} \mathrm{W}\right)$ in a water depth of 3890 meters in the axis of a half graben in the basement beneath the lower continental slope (Ryan et al., 1976).

\section{EXPERIMENTAL}

The core samples were freeze-dried, then extracted with toluene and methanol (3:7) in a Soxhlet apparatus (300 cycles of solvent change). The extracts for each sample were concentrated on a rotary evaporator, treated with $\mathrm{BF}_{3}$ in methanol to esterify free acids, then subjected to silica gel thin-layer chromatography (TLC) using methylene chloride as eluent. After development iodine vapor, the bands corresponding to hydrocarbons and esters with ketones were scraped off the TLC plate and eluted with methylene chloride. These fractions were subjected to gas chromatographic (GC) and mass spectrometric (MS) analyses.

The GC analyses were carried out on Hewlett-Packard Model 5830 gas chromatograph using a $30 \times$ $0.25 \mathrm{~mm}$ glass capillary column wall-coated with OV101 , programmed from 40 to $260^{\circ} \mathrm{C}$ at $4^{\circ} \mathrm{C}$ per

1 Contribution No. 1784 from Institute of Geophysics and Planetary Physics, University of California, Los Angeles, California. minute, then held isothermal for 80 minutes, using $\mathrm{He}$ carrier gas at a flow rate of $2 \mathrm{ml} / \mathrm{min}(30 \mathrm{~cm} / \mathrm{sec}$ linear velocity).

The GC/MS analyses were carried out on a Finnigan Model 4000 quadrupole mass spectrometer interfaced directly with a Finnigan Model 9610 gas chromatograph equipped with a $30 \mathrm{~m} \times 0.75 \mathrm{~mm}$ glass capillary column $(\mathrm{J}+\mathrm{W}$, Inc.) which was wall-coated with OV-101. The GC conditions for the GC/MS analyses were as those for the analytical GC system. The mass spectrometric data were acquired and processed using a Finnigan-Incos Model 2300 data system.

\section{Results and Discussion}

The sample descriptions and results of the carbon and lipid analyses are given in Table 1. The lipid yields were low and, for the Cretaceous samples, the $n$-fatty acid concentrations exceeded that of the $n$-alkanes. Ketones were present as minor components only. The distribution diagrams of the $n$-alkanes, $n$-fatty acids, and $n$-methylketones are shown in Figure 1.

The red nannoplankton, clay ooze (Sample 398D$40-4,140-150 \mathrm{~cm}$ ) from the lower Paleocene contained lipids attributable to mainly a bacterial origin. The narrow alkane distribution (cf. Figure 1A) with the dominance of $n-\mathrm{C}_{17}$ and $n-\mathrm{C}_{19}$ over $n-\mathrm{C}_{18}$ and the absence of homologs $>n-\mathrm{C}_{24}$ are indicative of bacterial lipids (Han et al., 1968). A further possible molecular marker of bacterial lipids are alkylcyclohexanes, which may be derived from cyclohexylalkanoic acids found in various bacteria (e.g., De Rosa et al., 1971). This sample contained a series of alkylcyclohexanes, $\mathrm{C}_{n} \mathrm{H}_{2 n}+1$ (Figure $2 \mathrm{~A}$ ), ranging from $n=15$ to 22 , with a maximum at $n=19$ and two isomeric series of alkylmethylcyclohexanes, $\mathrm{C}_{n} \mathrm{H}_{2 n}$ (Figure 2B), ranging from $n=16$ to 21 , with maxima at $n=19$. Alkylcyclohexanes have not been reported for marine sediments, but a monocyclic hydrocarbon $\left(\mathrm{C}_{20} \mathrm{H}_{40}\right)$ was identified in algal mat and sediment from Laguna Mormona, Baja California (Cardoso et al., 1976). Alkylcyclohexanes are found in petroleum as minor components. Thus, it cannot be 
TABLE 1

Sample Descriptions, Carbon Analyses, and Extract Yields for the Core Samples Examined

\begin{tabular}{|c|c|c|c|c|c|c|c|c|c|c|c|c|c|c|c|c|c|}
\hline \multirow{3}{*}{$\begin{array}{c}\text { Sample } \\
\text { (Interval in } \mathrm{cm} \text { ) }\end{array}$} & \multirow{3}{*}{$\begin{array}{l}\text { Sub- } \\
\text { Bottom } \\
\text { Depth } \\
(\mathrm{m})\end{array}$} & \multirow[b]{3}{*}{ Lithology } & \multirow{3}{*}{$\begin{array}{l}\text { Geologic } \\
\text { Age }\end{array}$} & \multicolumn{2}{|c|}{ Carbon ${ }^{\mathrm{a}}$} & \multirow{3}{*}{$\underset{(\%)}{\mathrm{CaCO}_{3}}$} & \multicolumn{11}{|c|}{ Lipids } \\
\hline & & & & \multirow{2}{*}{$\begin{array}{c}\text { Total } \\
(\%)\end{array}$} & \multirow{2}{*}{$\begin{array}{c}\text { Or. } \\
\text { ganic } \\
(\%)\end{array}$} & & \multirow{2}{*}{$\begin{array}{c}\text { Hydro- } \\
\text { carbons } \\
(\mu \mathrm{g} / \mathrm{g})\end{array}$} & \multicolumn{2}{|c|}{$n$-alkanes } & \multirow[b]{2}{*}{$\mathrm{Pr} / \mathrm{Ph}$} & \multirow{2}{*}{$\begin{array}{l}\text { Pery- } \\
\text { lene }\end{array}$} & \multicolumn{3}{|c|}{$n$-fatty acids } & \multicolumn{3}{|c|}{$n$-methylketones } \\
\hline & & & & & & & & $\overline{\mathrm{CPI}}$ & Maxima $^{b}$ & & & $(\mu \mathrm{g} / \mathrm{g})$ & CPI & $\operatorname{Maxima}^{b}$ & $(\mu \mathrm{g} / \mathrm{g})$ & CPI & Maxima $^{b}$ \\
\hline $\begin{array}{l}47 B-398 D-3-3 \\
120-150\end{array}$ & 322.8 & $\begin{array}{l}\text { Clay } \\
\text { nannofossil } \\
\text { ooze }\end{array}$ & $\begin{array}{l}\text { Late } \\
\text { Miocene }\end{array}$ & 7.99 & 0.09 & 66 & n.d. ${ }^{c}$ & - & - & - & - & n.d. & - & - & n.d. & - & - \\
\hline $\begin{array}{l}47 B-398 D-15-4, \\
130-150\end{array}$ & 552.4 & $\begin{array}{l}\text { Clay } \\
\text { nannofossil } \\
\text { ooze }\end{array}$ & $\begin{array}{l}\text { Late } \\
\text { Oligocene }\end{array}$ & 8.56 & 0.05 & 71 & n.d. & - & - & - & - & n.d. & - & - & n.d. & - & - \\
\hline $\begin{array}{l}47 \mathrm{~B}-398 \mathrm{D}-40-4, \\
140-150\end{array}$ & 789.9 & $\begin{array}{l}\text { Red } \\
\text { nannofossil } \\
\text { clay ooze }\end{array}$ & $\begin{array}{l}\text { Early } \\
\text { Paleocene }\end{array}$ & 5.07 & 0.07 & 42 & 3.0 & 1.7 & 19 & 1.3 & 0 & 0.5 & 6.5 & 16,26 & 0.04 & 1.29 & 18,25 \\
\hline $\begin{array}{l}47 \mathrm{~B}-398 \mathrm{D}-62-4, \\
135-150\end{array}$ & 1008.4 & $\begin{array}{l}\text { Gray } \\
\text { mudstone }\end{array}$ & $\begin{array}{l}\text { Cretaccous } \\
\text { (Albian) }\end{array}$ & 3.64 & 0.42 & 27 & n.d. & - & - & - & - & n.d. & - & - & n.d. & - & - \\
\hline $\begin{array}{l}47 \mathrm{~B}-398 \mathrm{D}-90-5, \\
15-30\end{array}$ & 1293.7 & $\begin{array}{l}\text { Gray } \\
\text { daystone }\end{array}$ & $\begin{array}{l}\text { Cretaceous } \\
\text { (Albian) }\end{array}$ & 0.94 & 0.78 & 1 & 0.5 & 1.4 & $\begin{array}{l}19,23 \\
29\end{array}$ & 1.1 & 0 & 2.5 & 4.4 & 16.28 & 0.25 & 2.22 & 19,25 \\
\hline $\begin{array}{l}\text { 47B-398D-97-3, } \\
0-20\end{array}$ & 1347.6 & $\begin{array}{l}\text { Black } \\
\text { claystone }\end{array}$ & $\begin{array}{l}\text { Cretaceous } \\
\text { (Albian) }\end{array}$ & 1.38 & 1.26 & 1 & n.d. & - & - & - & - & n.d. & - & - & n.d. & - & - \\
\hline $\begin{array}{l}\text { 47B-398D-122-5, } \\
132-142\end{array}$ & 1589.4 & $\begin{array}{l}\text { Gray } \\
\text { claystone }\end{array}$ & $\begin{array}{l}\text { Cretaceous } \\
\text { (Aptian) }\end{array}$ & 3.55 & 1.67 & 16 & 1.0 & 2.1 & $\begin{array}{l}17,19 \\
29\end{array}$ & 0.6 & tr. ${ }^{d}$ & 3.5 & 4.6 & 16,28 & 0.01 & 2.3 & 19,27 \\
\hline
\end{tabular}

${ }_{1}^{a}$ Data supplied by S. M. White, Deep Sea Drilling Project, Scripps Institution of Oceanography, Univer sity of California at San Diego.

The major maximum is italicized.

n.d. - not determined.

dir, - trace.

completely ruled out that these hydrocarbons may represent potential contamination by petroleum products. The $n$-fatty acids of this sample appear to have a dual source from autochthonous production $\left(n-\mathrm{C}_{12}\right.$ to $n-\mathrm{C}_{20}$, cf. Figure 1D) and probably an allochthonous terrigenous influx $\left(n-\mathrm{C}_{22}\right.$ to $\left.n-\mathrm{C}_{32}\right)$. Since the sediment was treated with $\mathrm{HCl}^{2}$ to remove carbonates before extraction, some of the allochthonous fatty acids may have been part of the carbonate matrix and thus unavailable to bacterial degradation. Dehydroabietic acid (Figure $2 \mathrm{C}$ ) is present as a minor component and is the predominant diterpenoid. This compound is a molecular marker of terrigenous resinous plants (Simoneit, 1977). Triterpenoidal, steroidal, and sesquiterpenoidal compounds are not present in significant amounts. Perylene is also absent. Traces of ketones are present and they consist of predominantly $n$-methylketones, $\mathrm{C}_{n} \mathrm{H}_{2 n} \mathrm{O}$, ranging from $n=12$ to 31 , with maxima at $n=18$ and 25 and a strong odd-to-even carbon number predominance $>C_{22}$ (cf. Figure $1 \mathrm{G}$ ). The homologs $>\mathrm{C}_{22}$ reflect a terrigenous origin and their distribution is analogous to those for samples from the Black Sea (Simoneit, 1978b). These compounds are probably derived from $n$-fatty acids or $n$-alkanes by microbial oxidation (Arpino, 1973). As a lesser constituent, 6, 10, 14-Trimethylpentadecan-2-one (Figure 2D) is present and its precursor is probably phytol from chlorophyll (Simoneit, 1973).

The Cretaceous samples (398D-90-5, 15-30 cm, and $398 \mathrm{D}-122-5,132-142 \mathrm{~cm}$ ) were deposited in a foreslope setting seaward of expanding deltas (Ryan et al., 1976). The sedimentation rates were estimated at a rapid 100 meters per million years, and the bottom waters were depleted in oxygen in the earlier paleoenvironments (Ryan et al., 1976). The Albian sample contained lipids of both an autochthonous marine and allochthonous terrigenous origin. The $n$-alkanes ranged from $\mathrm{C}_{12}$ to $\mathrm{C}_{33}$, with maxima at $\mathrm{C}_{19}, \mathrm{C}_{23}$ and an odd carbon number predominance from $\mathrm{C}_{25}$ to $\mathrm{C}_{31}$ (cf., Figure 1B). The maxima $<\mathrm{C}_{25}$ are indicative of microbially altered residues of lipids (Simoneit, in press). The $n$-fatty acids exhibit a bimodal distribution maximizing at $\mathrm{C}_{16}$ and $\mathrm{C}_{28}$ and ranging from $\mathrm{C}_{12}$ to $\mathrm{C}_{32}$ with a strong even-to-odd carbon number predominance (cf. Figure 1E). The homolog distribution $<C_{20}$ is typical of a marine origin (Boon et al., 1975, Simoneit, 1975) and $>C_{21}$ it is probably due to higher vascular plants (Hitchcock and Nichols, 1971; Simoneit, 1975). Dehydroabietic acid (Figure 2C) is also present as the predominant diterpenoid and it is a marker of terrigenous resinous plants (Simoneit, 1977). The more dominant marine character of these lipids supports a deep water paleoenvironment; the absence of perylene, with the $\mathrm{Pr} / \mathrm{Ph}>1$, indicates a more oxic water column (Didyk et al., 1978).

The Aptian sample contained lipids of predominantly a terrigenous origin. The $n$-alkanes exhibit a bimodal distribution maximizing at $\mathrm{C}_{17}$ and $\mathrm{C}_{29}$ and ranging from $\mathrm{C}_{13}$ to $\mathrm{C}_{35}$ with a strong odd-to-even carbon number predominance $>\mathrm{C}_{22}$ (cf., Figure $1 \mathrm{C}$ ). The homologs $>n-\mathrm{C}_{22}$ are typical of high plant wax (Simoneit, 1975). The $n$-fatty acids ranged from $C_{12}$ to $\mathrm{C}_{32}$, with maxima at $\mathrm{C}_{16}$ and $\mathrm{C}_{28}$ and a strong even-toodd carbon number predominance (cf. Figure 1F). The homologs $<\mathrm{C}_{20}$ are of a probable marine origin and those $>C_{22}$ are from a terrigenous higher plant source. Dehydroabietic acid (Figure 2C) is present and represents a marker of resinous plants. Perylene (Figure 2E) is present and, coupled with the $\mathrm{Pr} / \mathrm{Ph}$ of 0.6 , indicates anoxic paleoenvironmental conditions of sedimentation (Didyk et al.. 1978). The more dominant terrigenous character of these lipids, coupled with the indicators for an anoxic paleoenvironment, support the description of the sediment lithology, where a high rate of influx with limited microbial alteration of deltaic detritus had occurred. 

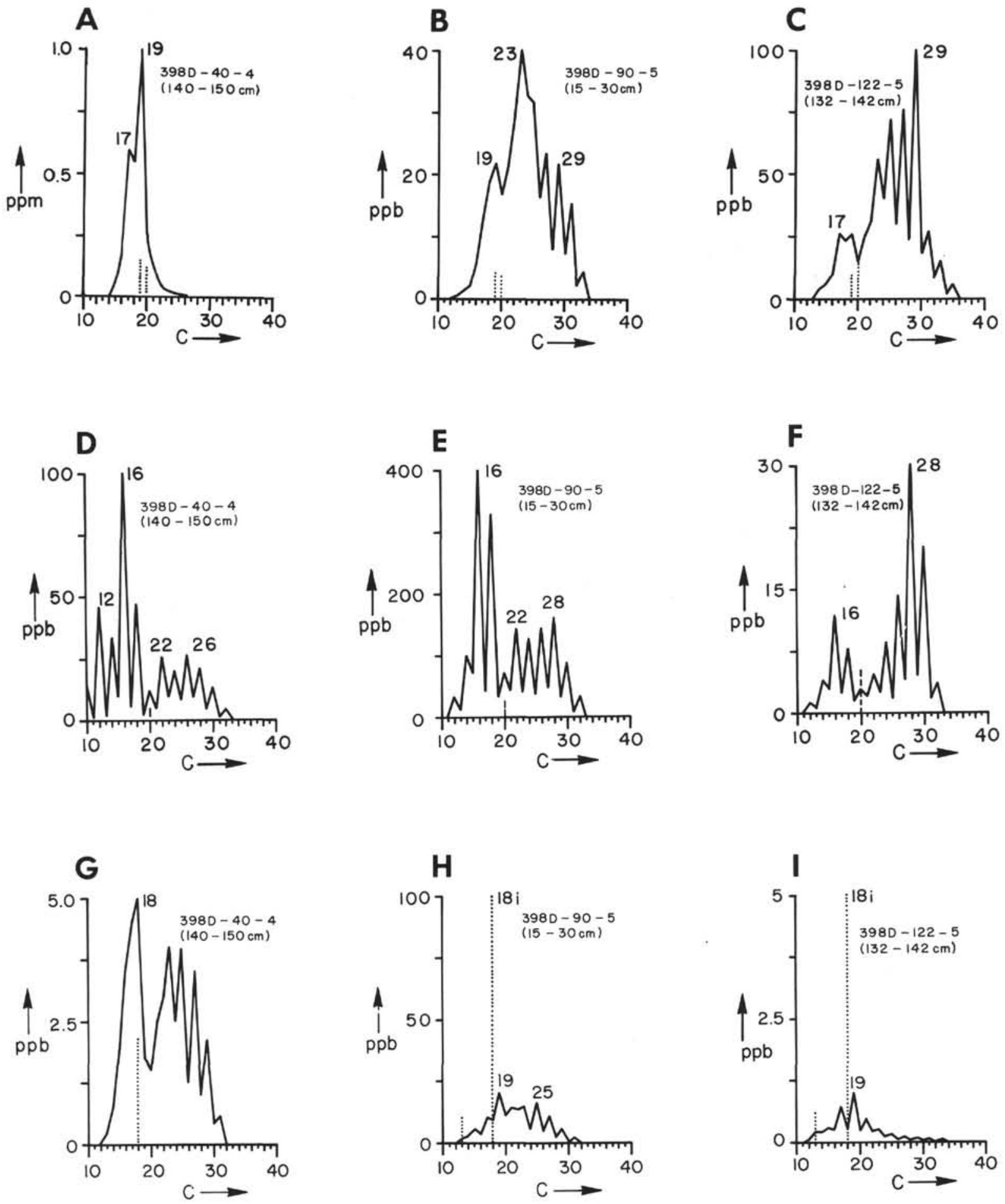

Figure 1. Distribution diagrams for $\mathrm{n}$-alkanes in $A$ to $C(\cdots=$ isoprenoids, height of line indicates approximate concentration); $\mathrm{n}$-fatty acids in $D$ to $F(--=$ diterpenoid); and n-methylketones in $G$ to $I(\ldots=$ isoprenoids).

The ketones of these two samples (cf. Figure 1H, I) consist of predominantly 6,10,14-trimethylpentadecan2-one (Figure 2D), lesser amounts of 6,10-dimethylundecan-2-one and $n$-methylketones, $\mathrm{C}_{n} \mathrm{H}_{2 n} \mathrm{O}$, ranging from $n=12$ to 33 , with an odd-to-even carbon number predominance and maxima at $\mathrm{C}_{19}$ and $\mathrm{C}_{25}$. The $n$-methylketones are derived from $n$-fatty acids or $n$-al- kanes by microbial oxidation and do not reflect a dominant terrigenous origin.

Other compounds that have been identified in the lipids of the Cretaceous samples consist of diterpenoidal, sesquiterpenoidal, and triterpenoidal hydrocarbons; ketones; and minor contaminants. Minor amounts of dehydroabietin (Figure 2F), two other iso- 

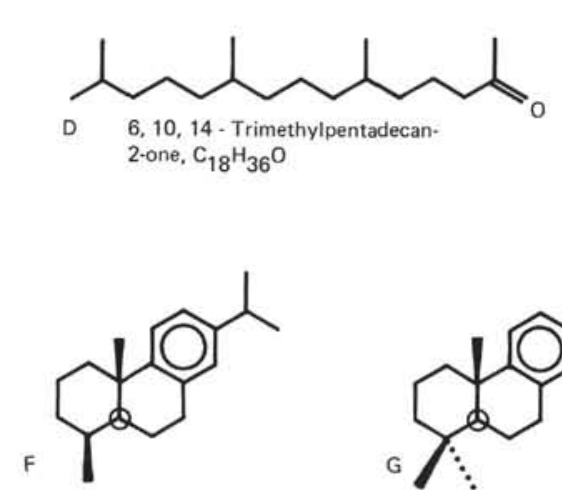

Dehydroabietin, $\mathrm{C}_{19} \mathrm{H}_{28}$

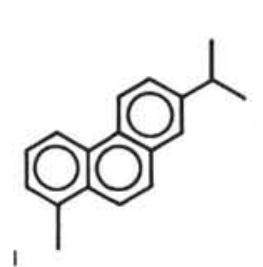

Retene, $\mathrm{C}_{18} \mathrm{H}_{18}$

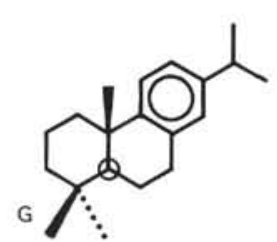
Dehydroabietane,
$\mathrm{C}_{20} \mathrm{H}_{30}$
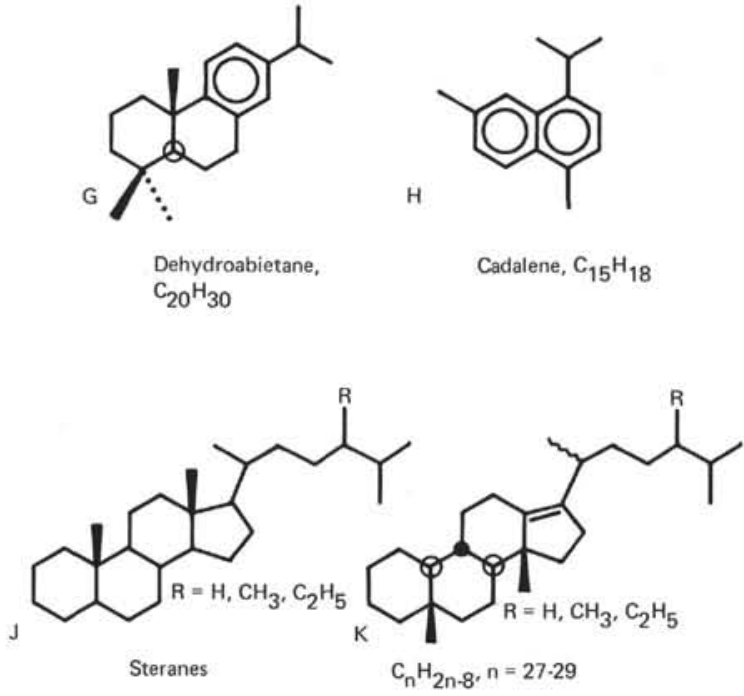

Cadalene, $\mathrm{C}_{15} \mathrm{H}_{18}$
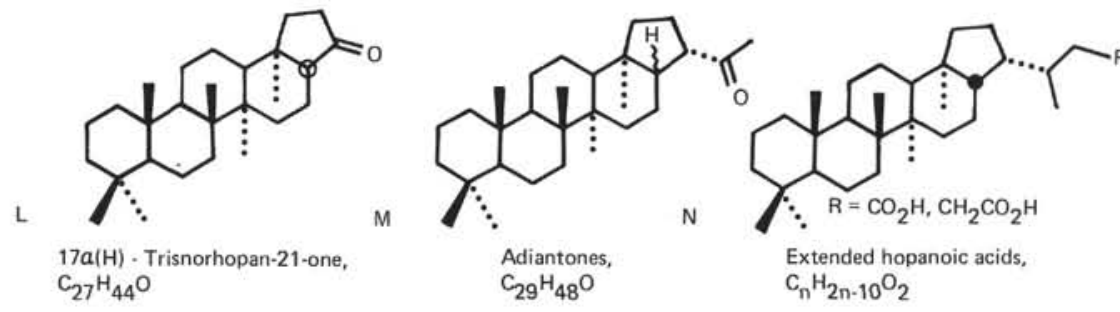

E

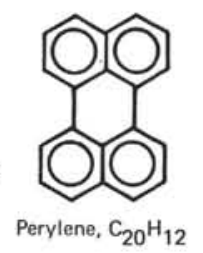

R
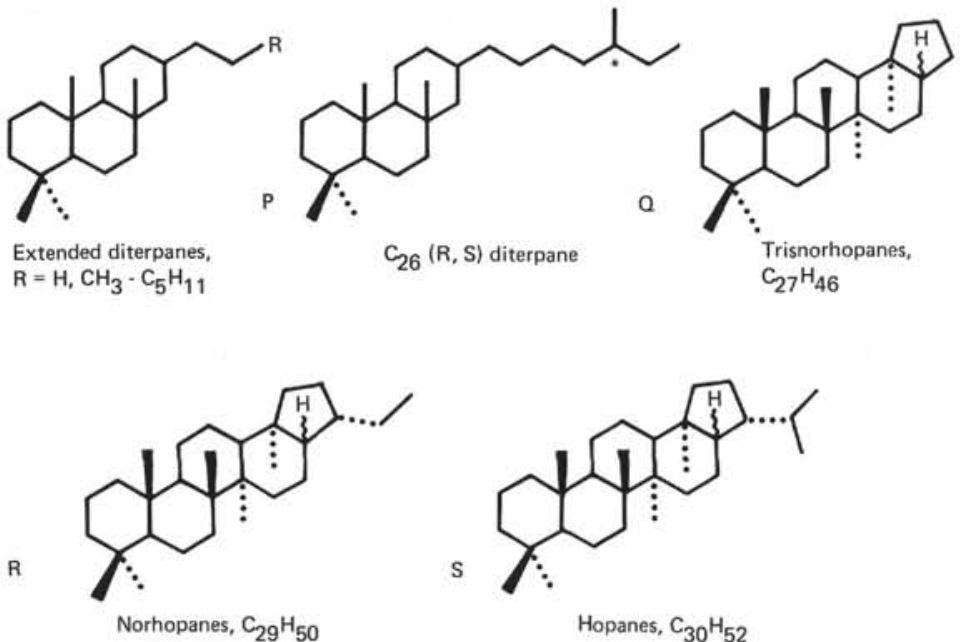

Hopanes, $\mathrm{C}_{30} \mathrm{H}_{52}$

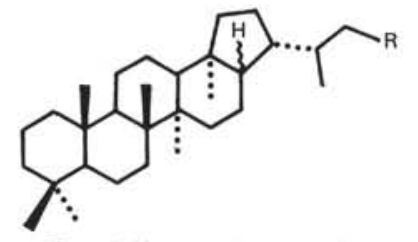

Figure 2. Chemical structures of Site 398 lipid components. 
mers, dehydroabietane (Figure $2 \mathrm{G}$ ), and cadalene (Figure $2 \mathrm{H}$ ), with a tetrahydro analog were present in the hydrocarbon fraction from Sample 398D-90-5, 15-30 $\mathrm{cm}$. Cadalene has previously been identified in petroleum (Bendoraitis, 1974) and in Sample 47A-397A-514, 100-112 cm (Simoneit and Mazurek, Volume 47, Part 1) Dehydroabietin (Figure 2F), retene (Figure 21) and an aromatic hydrocarbon, $\mathrm{C}_{17} \mathrm{H}_{14}$ (M.W. 218) were present as significant components in Sample 398D-122-5, 132-142 cm. Steranes (Figure 2J), ranging from $\mathrm{C}_{27}$ to $\mathrm{C}_{29}$ with probably the $5 \alpha$ stereochemistry, were present as trace components in both samples. The rearranged sterenes (probably $5 \beta, 14 \beta$-dimethyl-18, 19-dinorster-13(17)-ene, $\mathrm{C}_{n} \mathrm{H}_{2 n-8}$, Figure $2 \mathrm{~K}$ ) described by Rubinstein et al. (1975), were found as significant constituents for $n=27$ to 29 in the Aptian sample. The only triterpane that could be identified in this sample as a minor component was $17 \beta(\mathrm{H})$-homohopane. The ketone fraction of this sample contained minor amounts of $17 \alpha(\mathrm{H})$-trisnorhopane (Figure $2 \mathrm{~L}$ ); both $17 \alpha(\mathrm{H})$ - and $17 \beta(\mathrm{H})$-adiantone (Figure 2M); and three unknown triterpenoidal ketones: $\mathrm{C}_{29} \mathrm{H}_{50} \mathrm{O}\left(\mathrm{M}^{+}\right.$ 414 , base peak 231), $\mathrm{C}_{29} \mathrm{H}_{50} \mathrm{O}\left(\mathrm{M}^{+} 414\right.$, base peak 245), and $\mathrm{C}_{30} \mathrm{H}_{52} \mathrm{O}\left(\mathrm{M}^{+} 428\right.$, base peak 245$)$. The fatty acid fraction of this sample also contained $17 \beta(\mathrm{H})$ homohopanoic and $17 \beta(\mathrm{H})$-bishomohopanoic acids (Figure $2 \mathrm{~N}$ ). The presence of the $17 \beta$-triterpenoid skeletons in this Barremian sediment indicates that is is immature in terms of petrogenesis. However, the Albian sample contained a suite of both extended diterpenoids and predominantly $17 \alpha(\mathrm{H})$-triterpenoids, which are indicative of more mature lipids (Dastillung and Albrecht, 1976). The relative distribution of these compounds based on the m/e 191 peak intensity in the GC/MS data is given in Figure 3. The tricyclic diterpanes range from $\mathrm{C}_{20} \mathrm{H}_{36}$ to $\mathrm{C}_{26} \mathrm{H}_{48}$ and the presumed skeleton of the

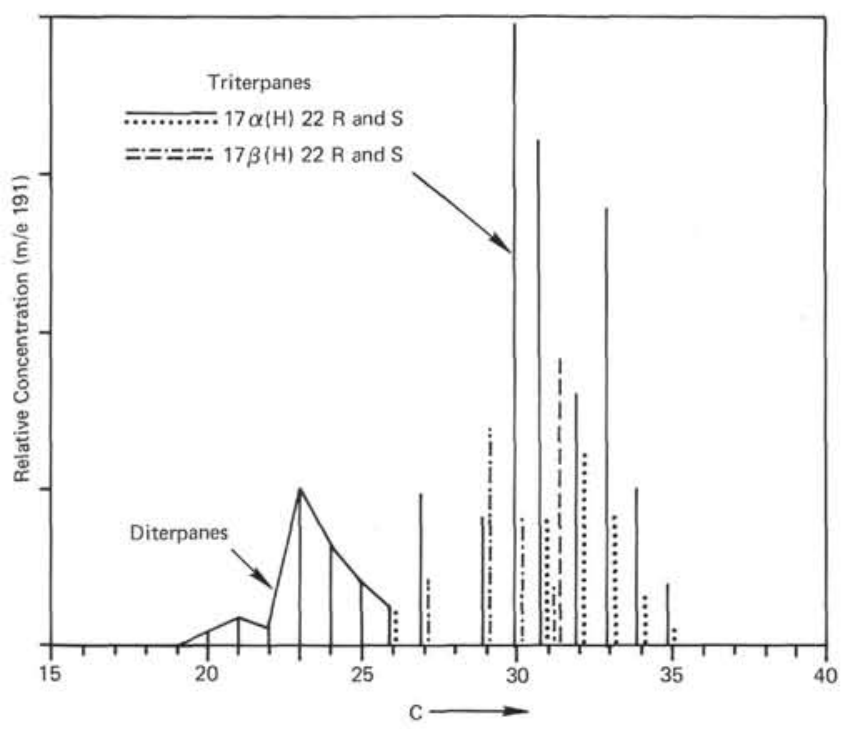

Figure 3. Relative distribution based on the m/e 191 mass chromatogram of diterpanes and triterpanes in Sample $398 D-90-5,15-30 \mathrm{~cm}$. (The $R$ and $S$ diastereomers are also indicated.)
$\mathrm{C}_{20}-\mathrm{C}_{25}$ homologs (Figure 2O) is based on the structure proposed for the m/e 191 fragment ion (Anders and Robinson, 1971). The $\mathrm{C}_{26} \mathrm{H}_{48}$ homolog was resolved into its $23 \mathrm{R}$ and $23 \mathrm{~S}$ diastereomers and, thus, the possible skeleton 8-methyl-13(5'-methylheptyl)podocarpane (Figure 2P). These compounds have been described in the bitumen of the Green River Shale (Anders and Robinson, 1971), and Reed (1977) described the series for the P.R. Spring Seep, Uinta Basin, but the $C_{26}$ homolog was not resolved. The triterpanes consist of $17 \alpha(\mathrm{H})$ - and $17 \beta(\mathrm{H})$-trisnorhopane (Figure 2Q), $17 \alpha(\mathrm{H})$ - and $17 \beta(\mathrm{H})$-norphopane (Figure $2 \mathrm{R}$ ), $17 \alpha(\mathrm{H})$ and $17 \beta(\mathrm{H})$-hopane (Figure $2 \mathrm{~S}), 22 \mathrm{R}$ and $22 \mathrm{~S}, 17 \beta(\mathrm{H})$ homohopane (Figure 2T) and $22 \mathrm{R}$ and $22 \mathrm{~S}, 17 \alpha(\mathrm{H})$ extended hopanes ranging from $\mathrm{C}_{31}$ to $\mathrm{C}_{35}$ (cf. Figure 3 ). The $22 \mathrm{R}$ and $22 \mathrm{~S}$ diastereomers of each of the $>\mathrm{C}_{31}$ triterpanes are present as a 1:1 mixture in mature sediments and petroleum, whereas in immature sediments only one diastereomer is present (Dastillung and Albrecht, 1976). The ratio of the diastereomers for this sample is $3: 1$, indicating an intermediate maturity. Contamination from various plasticizers was minor and consisted of ethyl, butyl, and octyl phthalates.

\section{CONCLUSIONS}

In the sample of early Paleocene age, the red ooze contained lipids characteristic of bacteria consisting of a narrow $n$-alkane distribution and the presence of alkylcyclohexanes. Traces of lipid residues from terrigenous sources were also present and consisted of $n$-fatty acids $>\mathrm{C}_{22}, n$-methylketones $>\mathrm{C}_{22}$, and dehydroabietic acid.

The lipids of the two Cretaceous samples reflected their depositional environment. The younger sample contained lipids of predominantly a marine origin with a minor influx of allochthonous terrigenous components. The paleoenvironment was oxic and the lipid organic matter was well along the path of petrogenic maturity. The older sample contained lipids of predominantly a terrigenous higher plant origin with a minor autochthonous component. The lipid organic matter was deposited in an anoxic environment and was immature.

\section{ACKNOWLEDGMENTS}

We thank the National Science Foundation for making the core samples available, and E. Ruth for assistance with GC/MS data acquisition. Partial financial assistance from the National Science Foundation (Grant No. OCE 76-21506) and from the Energy Research and Development Administration (Grant E[04-3]-34 P.A. 134) is gratefully acknowledged. We thank Dr. Shmuel Brenner and Dr. Ansis Kaneps for the review of the manuscript.

\section{REFERENCES}

Anders, D. E. and Robinson, W. E. 1971. Cycloalkane constituents of the bitumen from Green River Shale, Geochim. Cosmochim. Acta, v. 35, p. 661-678.

Arpino, 1973. Les lipides des sédiments lacustres éocènes, Thèse, Université Louis Pasteur de Strasbourg, France.

Bendoraitis, J. G., 1974. Hydrocarbons of biogenic origin in petroleum-aromatic triterpenes and bicyclic sequiterpenes. In Tissot, B. and Bienner, F. (Eds.), Advances in 
organic geochemistry 1973: Paris (Editions Technip), p. 209-224.

Boon, J. J., deLeeuw, J. W., and Schenck, P. A., 1975. Organic geochemistry of Walvis Bay diatomoceous ooze. I. Occurrence and significance of the fatty acids, Geochim. Cosmochim. Acta, v. 39 p. 1559-15.

Cardoso, J., Brooks, P. W., Eglinton, G., Goodfellow, R., Maxwell, J. R., and Philp, R. P., 1976. Lipids of recentlydeposited algal mats at Laguna Mormona, Baja California, In Nriagu, J. O. (Ed.), Environmental biogeochemistry: Ann Arbor (Ann Arbor, Science Publishers), p. 149174.

Dastillung, M. and Albrecht, P., 1976. Molecular test for oil pollution in surface sediments, Mar. Poll. Bull., v. 7, p. 1315.

De Rosa, M., Gambacorta, A., Minale L., and Bu'Lock, J. D. 1971. Bacterial triterpanes, Chem. Comm., p. 619-620.

Didyk, B. M., Simoneit, B. R. T., Brassell, S. C., and Eglinton G., 1978. Geochemical indicators of paleo-environmental conditions of sedimentation, Nature, v. 272, p. 216-222.

Han, J., McCarthy, E. D., Calvin, M., and Benn, M. H., 1968. Hydrocarbon constituents of the blue-green algae Nostoc muscorum, Anacystis nidulaus, Phormidium luridum and Chlorogloea fritschii, J. Chem. Soc. (C), p. 2785-2791.

Reed, W. E., 1977. Molecular compositions of weathered petroleum and comparison with its possible source, Geochim. Cosmochim. Acta, v. 41, p. 237-247.

Rubinstein, I., Sieskind, O., and Albrecht, P., 1975. Rearranged sterenes in a shale: Occurrence and simulated formation, J. Chem. Soc., Perkin Trans. I., p. 1833-1836.
Ryan, W. B. F., Sibuet, J.-C., Arthur, M., Mountain, G., Maldonado, A., Rehault, J. P., Lopatin, B. G., Moore, D. G., Iaccarino, S., Sigal, J., Blechschmidt, G., Habib, D., Morgan, G. E., Williams, C., Johnson, D., and Barnes, R., 1976. Passive Continental Margin, Geotimes, v. 21 p. 2124.

Simoneit, B. R. T., 1973. Appendix I. Identification of isoprenoidal ketones in Deep Sea Drilling Project core samples and their geochemical significance, In Burns, R. E., Andrews, J. E., et al., Initial Reports of the Deep Sea Drilling Project, v. 21: Washington, (U. S. Government Printing Office), p. 909-923.

1975. Sources of organic matter in oceanic sediments, Ph.D. Thesis, University of Bristol, England. 1977. Diterpenoid compounds and other lipids in deep-sea sediments and their geochemical significance, Geochim. Cosmochim. Acta, v. 41, p. 463-476.

1978a. Organic geochemistry of the shales and Sapropels of the Cretaceous Atlantic, 8th Internatl. Meeting on Organic Geochemistry, 8-13, May 1977, Moscow, p. $51-52$.

, in press. Terrigenous and marine organic markers and their input to marine sediments. In Baker, E. W. (Ed.), Proc. symp. organic geochemistry of DSDP sediments: Princeton (Science Press).

, 1978b. Organic geochemistry of terrigenous muds and various shales from the Black Sea, DSDP Leg 42B. In Ross, D., Neprochnov, Y., et al., Initial Reports of the Deep Sea Drilling Project, v. 42, Part 2: Washington, (U.S. Government Printing Office), p. 749-754. 